Check for updates

Cite this: Mater. Chem. Front., 2021, 5, 4950

Received 30th March 2021 Accepted 3rd May 2021

DOI: 10.1039/d1qm00479d

rsc.li/frontiers-materials

\section{Rational design of aqueous conjugated polymer nanoparticles as potential theranostic agents of breast cancer}

\author{
Panagiota Koralli, (D) ${ }^{a}$ Spyridon Tsikalakis, ${ }^{b}$ Maria Goulielmaki, (D) ${ }^{a}$ Stella Arelaki, ${ }^{c}$ \\ Janina Müller, (D) ${ }^{\text {bd }}$ Alkmini D. Nega, ${ }^{e}$ Friederike Herbst, ${ }^{c}$ Claudia R. Ball, ${ }^{f}$ \\ Vasilis G. Gregoriou, ${ }^{9}$ Antonia Dimitrakopoulou-Strauss, ${ }^{e}$ Stefan Wiemann ${ }^{\text {b }}$ and \\ Christos L. Chochos (iD *a
}

\begin{abstract}
Conjugated polymer nanoparticles (CPNs) have emerged as a new promising class of cancer theranostic agents due to their desirable optical features, such as high absorption coefficient and photoluminescence quantum yields, spanning from the ultraviolet to the near infrared, along with their photothermal and photodynamic properties. However, limited studies have been demonstrated up to now on the rational design of CPNs for specific biological purposes. In particular, it is not well understood how exactly the chemical structure of the conjugated polymer and the nanoparticle formulation approach (encapsulation versus nanoprecipitation) associates with the cytotoxicity, the intracellular uptake in vitro and the therapeutic behavior. For this reason, nanoprecipitated and encapsulated aqueous CPNs were formulated consisting of thiophene-quinoxaline type conjugated polymers varying as regards the number of the fluorine atoms (three versus four) on the repeat unit. The obtained CPNs were systematically examined in terms of cytotoxicity and intracellular uptake in vitro in three epithelial breast cell lines represented by one normal cell line, and two breast cancer cell lines composed of one luminal and one triple negative line. From the obtained results, it is presented that only the nanoprecipitated CPNs with the three fluorine atoms exhibited efficient intracellular uptake to all the epithelial cell lines tested, in addition to the visible fluorescence on the triple negative breast cancer cells. Moreover, evaluation of the comparison of the effect of the CPNs on cell proliferation and apoptosis of all cell lines with the corresponding antibiotic staurosporine was performed, indicating a putative therapeutic potential of nanoparticles under study.
\end{abstract}

\section{Introduction}

Cancer represents one of the leading causes of death worldwide. ${ }^{1}$ Since it is widely accepted that malignant cancer cells can be treated more successfully at the early stages of the disease, ${ }^{2}$ the necessity for reliable and trustworthy tumor recognition and monitoring is mandatory for diagnosis, imageguided surgery and evaluation of cancer therapeutics.,4 Nowadays, different noninvasive bioimaging techniques have been developed, which can provide pieces of information regarding the pathology and physiology of bioorganisms as well as to monitor biological processes. ${ }^{5,6}$ So far, various imaging modalities have been widely employed in biomedical diagnosis comprising ultrasound, ${ }^{7}$ optical imaging, ${ }^{8}$ computed tomography (CT), ${ }^{9,10}$ magnetic resonance imaging (MRI) ${ }^{11,12}$ and conventional scintigraphy, including single-photon emission computed tomography (SPECT) ${ }^{13}$ as well as, positron emission tomography (PET). ${ }^{14,15}$ Among them, fluorescence imaging techniques have 
become indispensable for biomedical imaging providing vital information. They can serve as a powerful modality for precancer diagnosis and post-cancer monitoring due to temporal resolution, high sensitivity, low cost, and the ability to use multiplexed signals with main applications in microscopy, spectroscopy, imaging probes and recently for image guided surgery. ${ }^{3}$ Notwithstanding that fluorescence techniques demonstrate many advantages, their main setbacks are shallow tissue penetration and low spatial resolution. ${ }^{16-18}$ These limitations are expected to be transcended by using far-red/near-infrared (FR/NIR) fluorescent dyes emitting in the spectral region between 600-1000 $\mathrm{nm}$, in which the interaction between light and biological species diminished. ${ }^{19}$

Over the past years, various types of fluorescent materials have been developed and extensively studied for FR/NIR fluorescence bioimaging, comprising organic dyes, ${ }^{20}$ fluorescent proteins, ${ }^{21,22}$ upconversion nanoparticles, ${ }^{23}$ inorganic semiconductor quantum dots (QDs), ${ }^{24,25}$ single-walled carbon nanotubes, ${ }^{26,27}$ as well as rare earth-doped nanoparticles. ${ }^{28,29}$ Nonetheless, each material has its own limitations that hinder their application in biomedicine, such as the chemical instability, aggregation-caused quenching (ACQ) effect, small Stokes shifts, photobleaching effect, low quantum yield (QY) and high intrinsic cytotoxicity levels. ${ }^{30-32}$

Consequently, the development of alternative FR/NIR fluorophores with high brightness, strong photobleaching resistance, large Stokes shift, photostability and low toxicity is highly covetable for modern bioimaging applications. Conjugated polymer nanoparticles (CPNs) have emerged as a new promising class of nanomaterials for fluorescence imaging taking advantage of its superior properties such as easy modification, highly efficient light-harvesting, high brightness, photostability, and high quantum yield, generated through fine-tuning of the backbone or side-chain structures, in combination with small particle size, low cytotoxicity and biocompatibility. ${ }^{18,33-35}$ Researchers currently show increasing attention to evolving CPNs for fluorescence imaging, multimodal molecular and cell imaging applications, drug/gene delivery and anticancer therapy. ${ }^{36-39}$

In an effort to create new far-red/NIR fluorescence bioimaging nanomaterials, we recently reported the rational design, systematic study and optimization of a series of donor-acceptor conjugated polymers consisting of thiophene as the electron donating and the quinoxaline as the electron deficient, varying as regards the number of the fluorine atoms anchored onto the polymer backbone, which were used for the formation of new water-soluble nanoparticles with high photoluminescence quantum yields. ${ }^{40}$ The aqueous nanoparticles were prepared using two methods; nanoprecipitation and encapsulation with the FDA and EMA approved mPLGA- $b$-PEG diblock copolymer. The TQ-based CPNs with the higher number of fluorine atoms on the polymer backbone, regardless of the preparation method, demonstrated desired emission in the FR/NIR region of the spectra (above $600 \mathrm{~nm}$ ) with quantum yield values of 0.18 enabling great prospect as FR/NIR fluorescent bioimaging dyes. Bearing in mind the specific CPNs' optical properties, we decided to perform in vitro studies on a superficial cancer type.

Among different types of superficial tumors, breast cancer represents the most commonly diagnosed cancer, accounting approximately for the $30 \%$ of all estimated new cancer cases globally in the female population and is regarded as the second leading cause of cancer-related mortality. ${ }^{41-43}$ Based on immunohistochemistry, breast cancer can be divided into three main subtypes according to the expression of three crucial receptors, which are estrogen receptor (ER), progesterone receptor (PR), human epidermal growth factor receptor 2 (HER2). If the tumors do not express any of these three receptors it is the so-called triple negative breast cancers (TNBC), making it difficult to target. ${ }^{44,45}$ Generally, most breast cancer diagnoses are related to luminal tumors, $20 \%$ relates to those that overexpress HER2, while only $15 \%$ refers to TNBC subtype. ${ }^{44}$ Even though the percentage of TNBC tumors among all breast cancer cases is relatively low, they represent the most aggressive phenotype ${ }^{46}$ with the highest rate of metastasis to other healthy organs, high proliferative index, high recurrence rate $(<5$ years $),{ }^{47}$ and a worse prognosis. ${ }^{48}$ Nowadays, the most common treatments for TNBC patients include surgery, radiotherapy and chemotherapy. ${ }^{46,49}$ During the last few years, CPNs have been reported as promising materials in photodynamic therapy of breast cancers. ${ }^{4-51}$

In this contribution, we performed in vitro studies in order to evaluate the cytotoxicity effects of the T2fQf and T2fQ2f (chemical structures on Fig. 1) far-red emitting aqueous conjugated polymer nanoparticles, which showed great promise as new FR/NIR fluorescent dyes according to our previous results. ${ }^{40}$ We used two different malignant human breast cell lines; a luminal type A (T-47D) and a triple negative (MDA-MB231) compared with a spontaneously immortalized nonmalignant epithelial cell line (MCF10A) for viability tests. To examine the cytotoxic effects of the CPNs on the cells depending on their preparation method (nanoprecipitation and encapsulation within mPLGA- $b$-PEG diblock copolymer), cell proliferation and late apoptotic cell numbers were evaluated over five days. The CPNs' ability to be introduced to the cells and their potential application for intracellular

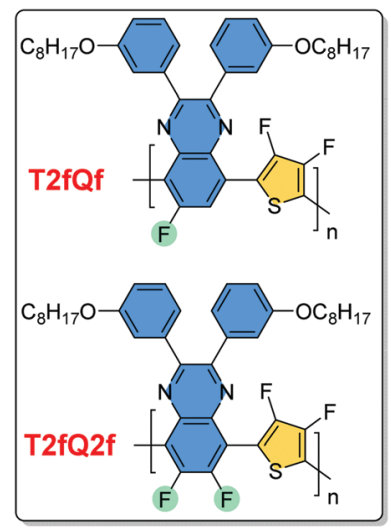

Fig. 1 The chemical structures of the T2fQf and T2fQ2f polymers used in this study in the form of aqueous nanoprecipitated or encapsulated CPNs. 
imaging protocols was investigated by confocal fluorescence microscopy and flow cytometry. Moreover, to evaluate the potential therapeutic response of CPNs, we compared the cell proliferation and apoptosis results with those of the antibiotic staurosporine. The obtained results revealed that the T2fQf CPNs prepared via the nanoprecipitation method are able to enter into MDA-MB-231 cells with high efficacy, to a lesser extent into T-47D cells, however, not into MCF10A. More interestingly, we observed that these specific CPNs trigger apoptosis in cancers cells, and not in normal-like cells making them an attractive candidate for further therapeutic interventions.

\section{Experimental}

\section{Synthesis of the TQ based polymers and nanoparticle's preparation}

The design, the synthesis and the characterization of the T2fQf and T2fQ2f conjugated polymers, as well as their corresponding aqueous CPNs are described in detail in our previous publication. ${ }^{40}$ In particular, for the formation of the CPNs via the nanoprecipitation method, first, each conjugated polymer was dissolved in tetrahydrofuran (THF) which is a low boiling point aprotic polar solvent miscible with water at a concentration of $0.1 \mathrm{mg} \mathrm{mL}{ }^{-1}$. Then, $1.5 \mathrm{~mL}$ of either T2fQf or T2fQ2f based THF solution (stock solution) was added dropwise to $7 \mathrm{~mL}$ of deionized water, respectively, followed by sonication at room temperature. For the encapsulation method, $1 \mathrm{mg}$ of each T2fQf and T2fQ2 $\mathrm{f}$ and $9 \mathrm{mg}$ of poly(ethylene glycol)methyl ether-block-poly(lactide-coglycolide) (mPEG- $b$-PLGA) were dissolved in $1 \mathrm{~mL}$ of THF. The resulting solutions are added to $7 \mathrm{~mL}$ of deionized water following the same procedure as described for the nanoprecipitation method.

In both cases, the solutions were left overnight to allow complete evaporation of the THF and the volume of water lost was replaced. After this procedure, stable aqueous CPNs are formed through aggregate formation of the hydrophobic conjugated polymer chains in the case of nanoprecipitation, whilst by applying the encapsulation method, the hydrophobic PLGA segments are liable to entangle with TQ polymer chains and the hydrophilic PEG chains should extend into the aqueous phase. The obtained CPNs were then filtered through a $0.2 \mu \mathrm{m}$ cellulose acetate filter.

We selected the T2fQf and T2fQ2f nanoparticles because they exhibit the highest fluorescence quantum yield among the other polymers in this series. In this work, the batch of the studied nanoparticles exhibit a hydrodynamic diameter of $74.8 \pm 0.3 \mathrm{~nm}$ for both the nanoprecipitated CPNs, $98.5 \pm$ $0.1 \mathrm{~nm}$ for the encapsulated T2fQ2f and $111.7 \pm 1.0 \mathrm{~nm}$ for the encapsulated T2fQf. The resulting concentrations of the CPNs prepared via the nanoprecipitation method were $5.7 \mu \mathrm{g} \mathrm{mL}^{-1}$ for the T2fQf polymer and $4.3 \mu \mathrm{g} \mathrm{mL} \mathrm{m}^{-1}$ for the T2fQ2f polymer, and $1430 \mu \mathrm{g} \mathrm{mL}{ }^{-1}$ for the CPNs prepared via the encapsulation method.

\section{Cell lines and culture}

Two breast cancer cell lines, T-47D (CVCL_0553) and MDA-MB231 (CVCL_0062), along with MCF10A (CVCL_0598), an immortalized breast epithelial ("normal-like") cell line, were acquired from ATCC (LGC Standards GmbH, Wesel, Germany). The cell lines were repeatedly authenticated using SNP profiling (Multiplexion GmbH, Friedrichshafen, Germany) and all experiments were performed with mycoplasma-free cells. Cells were grown in $75 \mathrm{~cm}^{2}$ flasks (Corning) in the appropriate culture medium. T-47D and MDA-MB-231 cells were cultured in RPMI1640, supplemented with 10\% FBS and 1\% NEAA (all from Thermofisher Scientific). For MCF10A cells, DMEM-F12 supplemented with 5\% Horse Serum (life technologies), $10 \mu \mathrm{g} \mathrm{mL} \mathrm{m}^{-1}$ Insulin (Sigma), $20 \mathrm{ng} \mathrm{mL}{ }^{-1}$ Epidermal growth factor (Corning), $0.5 \mu \mathrm{g} \mathrm{mL} \mathrm{m}^{-1}$ Hydrocortisone (Sigma) and $100 \mathrm{ng} \mathrm{mL}^{-1}$ Cholera toxin (Sigma) was used. All media were supplemented with 50 units per $\mathrm{mL}$ penicillin and $50 \mu \mathrm{g} \mathrm{mL}^{-1}$ streptomycin sulfate (Invitrogen). The cells were maintained in a humidified chamber with $5 \% \mathrm{CO}_{2}$ at $37{ }^{\circ} \mathrm{C}$ with media changes every $3-4$ days until $70 \%-80 \%$ confluency.

\section{Cell viability and cytotoxicity assessment}

T-47D and MDA-MB-231, along with MCF10A were used in order to evaluate the putative effects of the newly synthesized TQ based polymers on cell viability and apoptotic cell death. For cytotoxicity assessment, cell proliferation over five days was evaluated using DAPI/Hoechst staining, while the late apoptotic cell numbers were recorded by Propidium Iodide (PI) staining. $1.5 \times 10^{3}$ T-47D and MDA-MB-231 cells and $2 \times 10^{3}$ MCF10A cells were seeded in 96well plates, in five technical replicates. The following day, the culture medium was substituted with CPN-containing media at 6 different concentrations: for nanoprecipitated T2fQf: $1.59 \mu \mathrm{g} \mathrm{mL} \mathrm{mL}^{-1}, 0.53 \mu \mathrm{g} \mathrm{mL} \mathrm{m}^{-1}, 0.176 \mu \mathrm{g} \mathrm{mL} \mathrm{L}^{-1}$, $0.059 \mu \mathrm{g} \mathrm{mL} L^{-1}, 0.019 \mu \mathrm{g} \mathrm{mL}^{-1}$ and $0 \mu \mathrm{g} \mathrm{mL}^{-1}$; for nanoprecipitated T2fQ2f: $1.2 \mu \mathrm{g} \mathrm{mL} \mathrm{mL}^{-1}, 0.4 \mu \mathrm{g} \mathrm{mL}^{-1}, 0.133 \mu \mathrm{g} \mathrm{mL}^{-1}$, $0.044 \mu \mathrm{g} \mathrm{mL} L^{-1}, 0.015 \mu \mathrm{g} \mathrm{mL} L^{-1}$ and $0 \mu \mathrm{g} \mathrm{mL}^{-1}$; for encapsulated T2fQf and T2fQ2f the following concentrations were applied:

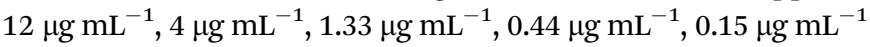
and $0 \mu \mathrm{g} \mathrm{mL} L^{-1}$. In all cases, the concentration of $0 \mu \mathrm{g} \mathrm{mL} L^{-1}$ was used as a negative control. The antibiotic staurosporine was used as a positive control. In order to define a starting concentration for the use of staurosporine, a preliminary toxicity test on all three cell lines was performed, with the following range of concentrations: $10 \mu \mathrm{g} \mathrm{mL} L^{-1}, 7.5 \mu \mathrm{g} \mathrm{mL}{ }^{-1}, 5 \mu \mathrm{g} \mu \mathrm{mL}^{-1}, 2.5 \mu \mathrm{g} \mathrm{mL} L^{-1}, 1.25 \mu \mathrm{gL}^{-1}$, $0.625 \mu \mathrm{g} \mathrm{mL} L^{-1}, 0.313 \mu \mathrm{g} \mathrm{mL} L^{-1}$ and $0.156 \mu \mathrm{g} \mathrm{mL} L^{-1}$. In all cell lines, all concentrations killed the cells after 2 days, except for the $0.156 \mu \mathrm{g} \mathrm{mL}^{-1}$ concentration, which impeded the growth of all the cell lines but did not completely eliminate the cells. Hence, the following concentrations were used for the screening experiment: $0.360 \mu \mathrm{g} \mathrm{mL}{ }^{-1}$ was used as the starting concentration, and then the following concentrations were made in serial dilutions of $1 / 3$ : $0.120 \mu \mathrm{g} \mathrm{mL}^{-1}, \quad 0.040 \mu \mathrm{g} \mathrm{mL}^{-1}, \quad 0.0133 \mu \mathrm{g} \mathrm{mL} \mathrm{mL}^{-1}$ and $0.0044 \mu \mathrm{g} \mathrm{mL}{ }^{-1}$ were prepared. Immediately after this (day 0 ), and each following day (up to day 4), the cells in respective replicate plates were stained with Hoechst and PI and fluorescent signals were acquired using a microplate reader. Results were analyzed in OriginPro9 and mean values and standard deviations were estimated. All data are presented as the mean \pm standard error. 


\section{Quantification of cellular incorporation of the TQs by FACS analysis}

Cells were seeded in triplicate, in 6 well plates $\left(1 \times 10^{5} \mathrm{MCF} 10 \mathrm{~A}\right.$ cells per well; $2 \times 10^{5}$ MDA-MB-231 cells per well; $3 \times 10^{5} \mathrm{~T}-47 \mathrm{D}$ cells per well) and in the appropriate culture medium, at $37{ }^{\circ} \mathrm{C}$ for $24 \mathrm{~h}$. The next day, the medium was removed and the cells were subjected to $24 \mathrm{~h}$-treatment with medium containing one of the following: nanoprecipitated T2fQf $\left(0.176 \mu \mathrm{g} \mathrm{mL} L^{-1}\right)$, nanoprecipitated T2fQ2f $\left(0.133 \mu \mathrm{g} \mathrm{mL}{ }^{-1}\right)$, encapsulated T2fQf $\left(1.33 \mu \mathrm{g} \mathrm{mL} \mathrm{m}^{-1}\right)$, or encapsulated T2fQ2f $\left(1.33 \mu \mathrm{g} \mathrm{mL} \mathrm{m}^{-1}\right)$. After the end of the incubation period, cells were washed with PBS, trypsinized and resuspended in PBS. $15 \times 10^{3}$ cells were analysed for each of the tested conditions, via FACS (FACS Calibur $^{\mathrm{TM}}$, BD Biosciences), with an excitation wavelength of $488 \mathrm{~nm}$ and an emission wavelength of $670 \mathrm{~nm}$. Living cells were gated in forward versus side scatter with dead cells being excluded. Gating for distinguishing negative and positive cells was determined by the negative controls (cells treated with PBS). Means and standard deviations of biological replicates were determined. Unpaired two-tailed student $t$-test was used to calculate $p$ value.

\section{Fluorescence staining of cell-incorporated TQS}

Cells were seeded onto coverslips in 6 well plates (MCF10A: $1 \times$ $10^{5}$ cells per well, MDA-MB-231: $2 \times 10^{5}$ cells per well, T-47D: $3 \times 10^{5}$ cells per well) in the appropriate culture medium, at $37{ }^{\circ} \mathrm{C}$ for $24 \mathrm{~h}$. Three coverslips were placed in each well to generate triplicate samples. The next day, the medium was removed and the cells were subjected to $24 \mathrm{~h}$-treatment with medium containing one of the following: nanoprecipitated T2fQf $\left(0.176 \mu \mathrm{g} \mathrm{mL}{ }^{-1}\right)$, nanoprecipitated T2fQ2f $\left(0.133 \mu \mathrm{g} \mathrm{mL}{ }^{-1}\right)$, encapsulated T2fQf $\left(1.33 \mu \mathrm{g} \mathrm{mL} \mathrm{m}^{-1}\right)$, or encapsulated T2fQ2f $\left(1.33 \mu \mathrm{g} \mathrm{mL}{ }^{-1}\right)$. After two washes with phosphate-buffer saline (PBS), the cells were fixed with $4 \%$ paraformaldehyde. Two more washing steps followed and counterstaining of cell nuclei was performed using the cell-permeable Hoechst Fluorescent dye 33342 (Sigma Aldrich). Samples were mounted and visualized using a motorized inverted confocal microscope (Zeiss LSM 710 ConfoCor 3, two reflected light PMTs detectors, objectives $40 \times / 1.3$ Oil DIC III and $63 \times / 1.4$ Oil DIC III). Two different laser lines were used for the detection of nanoparticles, namely DPSS $(561 \mathrm{~nm})$ and HeNe $1(594 \mathrm{~nm})$, and UV diode $(405 \mathrm{~nm})$ laser line was used for the detection of Hoechst. Zeiss ZEN 2.6 and Image J software programs were used for image acquisition.

\section{Results and discussion}

In our previous work $^{40}$ we prepared 12 different TQ-based aqueous CPNs varying as regards the number and positioning of the fluorine atoms on the polymer backbone using two methods; nanoprecipitation and encapsulation with the FDA and EMA approved mPLGA- $b$-PEG diblock copolymer. We detected that the TQ-based CPNs with the three (T2fQf) and four (T2fQ2f) fluorine atoms on the polymer backbone, regardless of the preparation method, demonstrated desired emission in the FR/NIR region of the spectra (above $600 \mathrm{~nm}$ ) with higher quantum yield values of 0.18 enabling great prospect as FR/NIR fluorescent bioimaging dyes. Bearing in mind the specific CPNs' optical properties, we decided to perform in vitro studies on the T2fQf and T2fQ2f nanoprecipitated and encapsulated nanoparticles on a superficial cancer type.

\section{Cell proliferation and cytotoxicity studies}

To use the synthesized CPNs for bioimaging applications, we first examined their effect on cell proliferation and viability of two distinct breast cancer cell lines in vitro, in juxtaposition with a non-tumorigenic epithelial cell line of the same tissue origin. Cell proliferation and late apoptosis studies were performed in parallel, using DAPI/Hoechst and Propidium Iodide (PI) staining, respectively, after incubating the cells with increasing concentrations of the nanoprecipitated (Fig. 2A and $3 \mathrm{~A}$ ) or encapsulated (Fig. 2B and 3B) nanoparticles over a period of four days.

Our results show that low concentrations of nanoprecipitated T2fQf (up to $0.059 \mu \mathrm{g} \mathrm{mL}^{-1}$ ) do not affect the proliferation of the cancer cell line MDA-MB-231, while MCF10A cells continue to grow even after treatment at higher concentrations (up to $0.53 \mu \mathrm{g} \mathrm{mL}^{-1}$ ) of the specific type $\mathrm{CPN}$, as compared to untreated control (Fig. 2A, upper row). Regarding T-47D cells, higher concentrations of nanoprecipitated T2fQf do not affect the cell proliferation rate up to 3 days of treatment. Nevertheless, there is a more profound effect on apoptosis of cancer cells, since late apoptotic cell numbers in MDA-MB-231 and T-47D increase over time by more than 10 folds after treatment with increasing concentrations of nanoprecipitated T2fQf (Fig. 2A, lower row). Interestingly, $1.59 \mu \mathrm{g} \mathrm{mL} \mathrm{m}^{-1}$ of nanoprecipitated T2fQf could potentially act cytostatically or induce non-apoptotic cell death in MDA-MB-231 cells, since it suppresses cell proliferation, while not increasing late apoptotic cell counts over time. Low concentrations of the nanoprecipitated T2fQf do not induce apoptosis in MCF10A.

Regarding the effect of the encapsulated T2fQf nanoparticles, they are generally better tolerated by cancer cells, rather than by non-tumorigenic ones. More specifically, neither cell proliferation nor apoptosis of MDA-MB-231 and T-47D are affected even by higher concentrations of the encapsulated T2fQf (up to $4 \mu \mathrm{g} \mathrm{mL} \mathrm{m}^{-1}$ ) (Fig. 2B). However, while the proliferation of MCF10A cells is not affected by encapsulated T2fQf (Fig. 2B, upper row), there is a significant increase in late apoptotic cell numbers after early time-point treatment, that is sustained over time, even in lower concentrations of the CPNs, as compared to the untreated control cells (Fig. 2B, lower row). In total, our results show that encapsulation of T2fQf renders the particles to be better tolerated by cancer cells, but it induces apoptotic cell death in the non-tumorigenic MCF10A cells. For this reason, nanoprecipitated T2fQf in low concentrations would probably be a better choice for cell imaging applications since it is better tolerated by noncancerous cells.

Similar results, but with few significant differences, were obtained after treating the selected cell lines with 


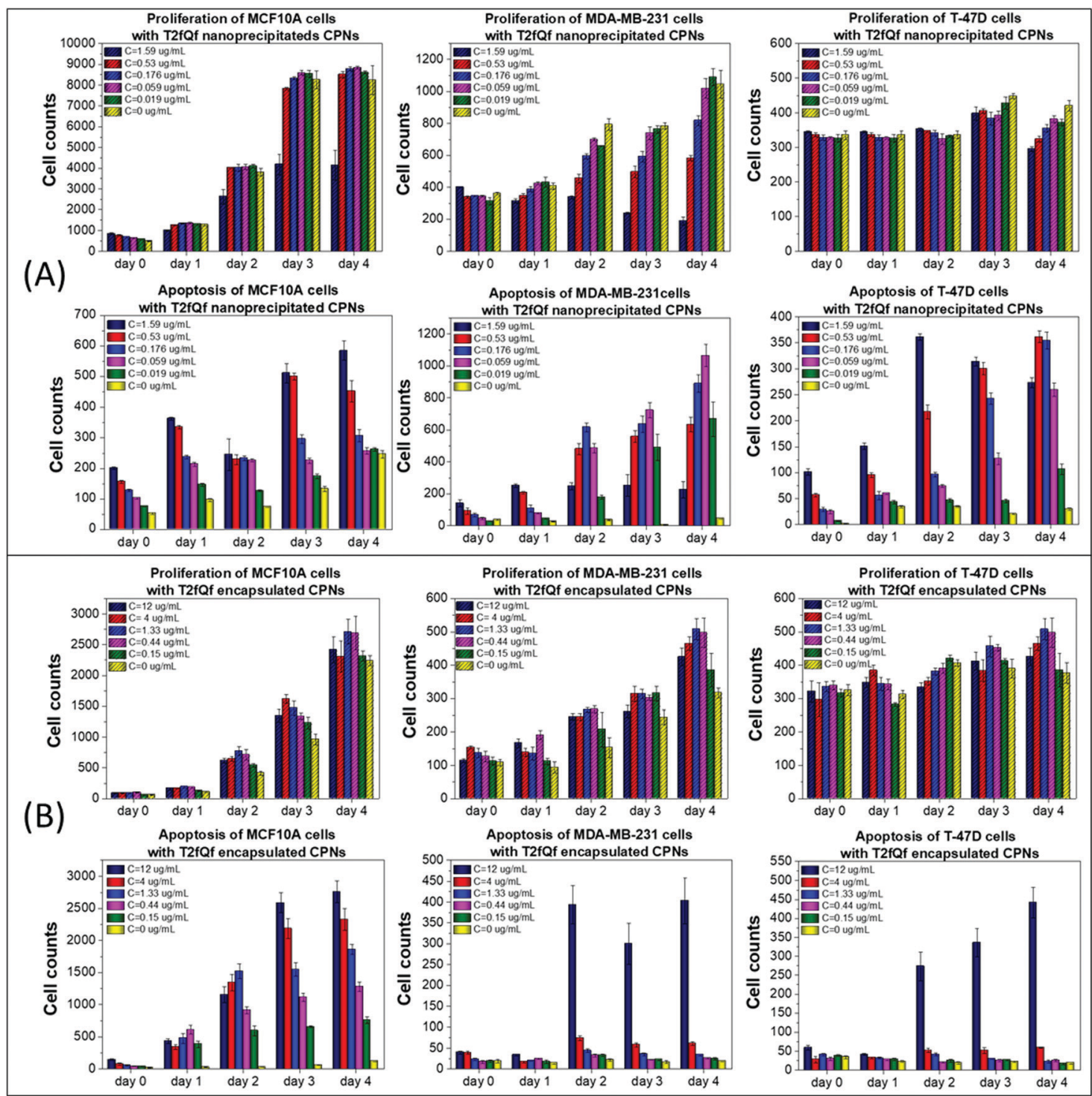

Fig. 2 Effect of T2fQf on the proliferation (upper row) and apoptosis (lower row) of human breast cancer cell lines MDA-MB-231 and T-47D and of the normal-like breast epithelial cell line MCF10A. Cell proliferation and late apoptotic cell numbers were estimated by Hoechst/DAPI and PI staining, respectively, after treatment of the cells with increasing concentrations of T2fQf acquired by $(A)$ the nanoprecipitation method $\left(c=0.019-1.59 \mu \mathrm{g} \mathrm{mL}{ }^{-1}\right.$ ), or (B) the encapsulation method ( $\left.c=0.15-12 \mu \mathrm{g} \mathrm{mL}^{-1}\right)$, every $24 \mathrm{~h}$, over a period of four days. Untreated cells $\left(c=0 \mu \mathrm{g} \mathrm{mL} \mathrm{L}^{-1}\right)$ were used as a negative control. Day 0 is the day of treatment initiation data $(n=5)$ are presented as mean of cell counts compared with the negative control. SD was used for error bar generation.

nanoprecipitated T2fQ2f nanoparticles. Firstly, the nanoprecipitated T2fQ2f nanoparticles are better tolerated by MCF10A cells than nanoprecipitated T2fQf (administered in similar concentrations), since they do not block the proliferation or induce apoptosis after 4 days of treatment, even at higher concentrations, as compared to the negative control (Fig. 3A, 1st column); thus, along with nanoprecipitated T2fQf, it could also be further exploited for bio-imaging applications.

In MDA-MB-231 cells, proliferation is slightly blocked up to the third day, an effect that is restored after four days of treatment with concentrations up to $0.133 \mu \mathrm{g} \mathrm{mL}{ }^{-1}$. Apoptotic cell death is triggered from the second day of treatment, even in lower CPN concentrations (Fig. 3A, 2nd column). Interestingly,
1.2 $\mu \mathrm{g} \mathrm{mL} \mathrm{m}^{-1}$ of nanoprecipitated $\mathrm{T} 2 \mathrm{fQ} 2 \mathrm{f}$ act similarly to $1.59 \mu \mathrm{g} \mathrm{mL} \mathrm{L}^{-1}$ of nanoprecipitated T2fQf in the specific cell line-cytostatic action or induction of non-apoptotic cell death-, since it reduces cell proliferation, with steady late apoptotic cell counts over time. In T-47D cell line, cells proliferate normally until day 2, while there is a slight blockade in the proliferation rate in more extended periods of treatment with increasing concentrations of nanoprecipitated T2fQ2f. Notably, apoptosis is triggered only by the two highest concentrations and only after four days of incubation with the specific CPNs (Fig. 3A, 3rd column). As shown in Fig. 3B, encapsulation of T2fQ2f renders it non-cytotoxic to all tested cell lines, since there are only small differences in cell proliferation and apoptosis in the 


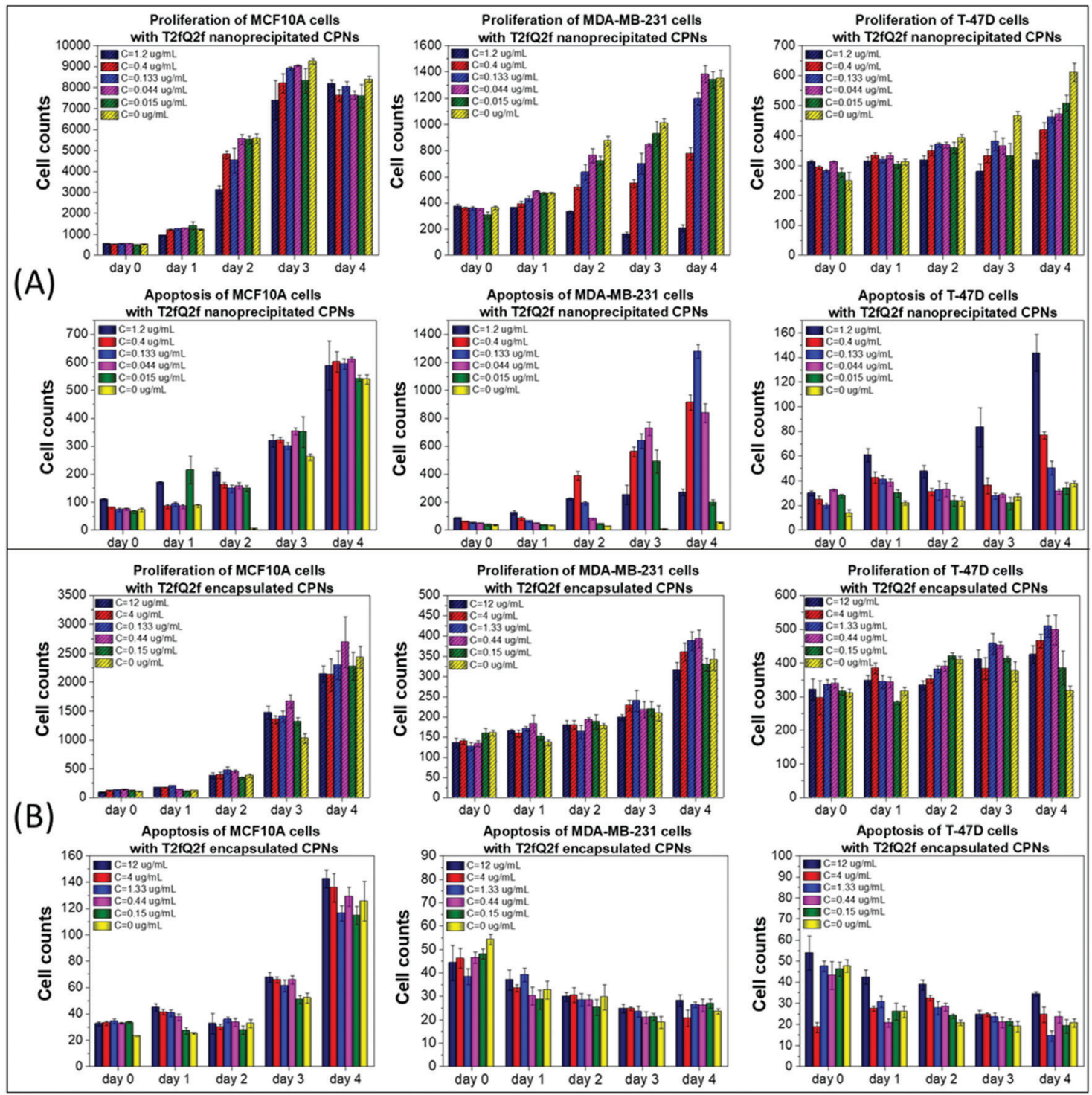

Fig. 3 Effect of T2fQ2f on the proliferation (upper row) and apoptosis (lower row) of human breast cancer cell lines MDA-MB-231 and T-47D and of the normal-like breast epithelial cell line MCF10A. Cell proliferation and late apoptotic cell numbers were estimated by Hoechst/DAPI and PI staining, respectively, after treatment of the cells with increasing concentrations of T2fQ2f acquired by (A) the nanoprecipitation method $\left(c=0.015-1.2 \mu \mathrm{g} \mathrm{mL}{ }^{-1}\right.$ ), or (B) the encapsulation method $\left(c=0.15-12 \mu \mathrm{g} \mathrm{mL} L^{-1}\right)$, every $24 \mathrm{~h}$, over a period of four days. Untreated cells $\left(c=0 \mu \mathrm{g} \mathrm{mL} \mathrm{L}^{-1}\right)$ were used as a negative control. Day 0 is the day of treatment initiation data $(n=5)$ are presented as mean of cell counts compared with the negative control. SD was used for error bar generation.

CPN-treated cells compared to untreated control, and only at higher concentrations of the encapsulated T2fQ2f nanoparticles.

Next, we compared the above-mentioned effects of the nanoprecipitated and encapsulated nanoparticles on cell proliferation and apoptosis of MCF10A, MDA-MB-231 and T-47D with those of the antibiotic staurosporine, to evaluate potential therapeutic responses (Fig. 4 and 5). Staurosporine is an inducer of apoptosis and is commonly used as a positive control for apoptotic cell death in cancer cells, including breast cancer cell lines. ${ }^{52,53}$ Here, we should point out that the nanoprecipitated CPNs were administered in similar concentrations to that of staurosporine, and thus a more quantitative comparison of the effects could take place. Nevertheless, the tested concentrations of the encapsulated CPNs were about 10-fold higher than those of the antibiotic, and consequently, the comparison of the effects can only be made on a qualitative basis.

On the one hand, MCF10A cells are more sensitive to staurosporine versus the nanoprecipitated T2fQf or T2fQ2f when administered in similar concentrations, since it significantly suppresses cell proliferation and slightly increases apoptosis even from the first day of treatment and throughout the experiment. On the other hand, nanoprecipitated T2fQf induces apoptosis to a lower extent (about 30\% increase in apoptotic cell number, in comparison to about 7 -fold increase by staurosporine by day 4 compared to day 0 , in the corresponding highest tested concentration) (Fig. 4A), while the nanoprecipitated T2fQ2f does not have any significant effect on proliferation and apoptosis (Fig. 5A). 


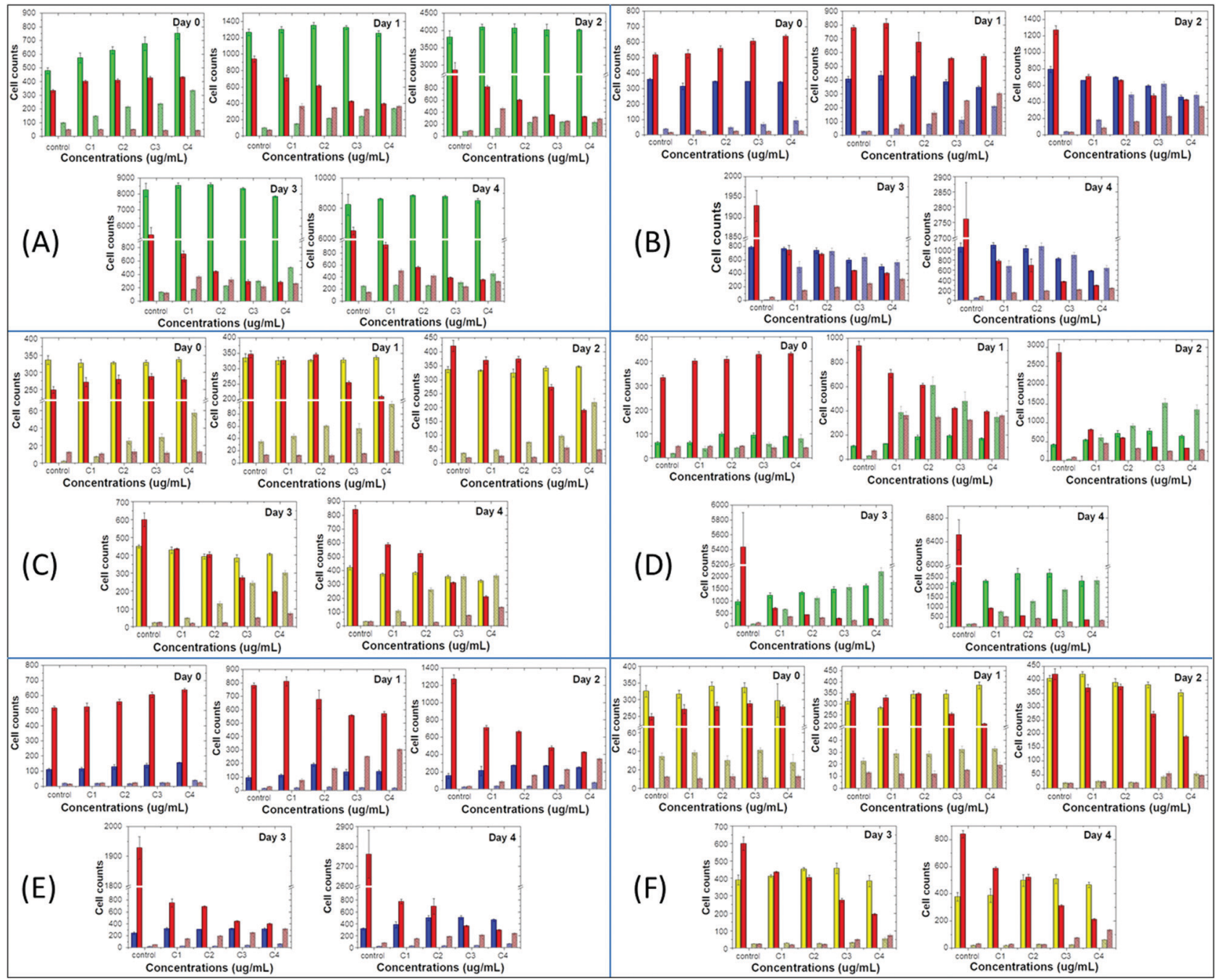

Fig. 4 Comparison of the effect of T2fQf with that of the antibiotic staurosporine on the proliferation and apoptosis of breast cancer and nontumorigenic cell lines. Cell proliferation and late apoptotic cell numbers were estimated for MCF10A (A and D), MDA-MB-231 (B and E) and T-47D cells ( $C$ and F), by Hoechst/DAPI and PI staining, respectively, after treatment of the cells with increasing concentrations of staurosporine and T2fQf acquired by either the nanoprecipitation $(A-C)$, or the encapsulation $(D-F)$ method, every $24 \mathrm{~h}$, over a period of four days. Day 0 is the day of treatment initiation. Data are presented as mean of cell counts compared with the negative control. SD was used for error bar generation. For staurosporine, the following concentrations were used: control: $0.0044 \mu \mathrm{g} \mathrm{mL}^{-1}, \mathrm{C} 1: 0.0133 \mu \mathrm{g} \mathrm{mL}^{-1}, \mathrm{C} 2: 0.040 \mu \mathrm{g} \mathrm{mL}^{-1}, \mathrm{C} 3: 0.120 \mu \mathrm{g} \mathrm{mL}{ }^{-1}, \mathrm{C} 4: 0.360 \mu \mathrm{g} \mathrm{mL}{ }^{-1}$. The corresponding concentrations for nanoprecipitated T2fQf were: control: $0 \mu \mathrm{g} \mathrm{mL}^{-1}, \mathrm{C} 1: 0.019 \mu \mathrm{g} \mathrm{mL}^{-1}, \mathrm{C} 2: 0.059 \mu \mathrm{g} \mathrm{mL}^{-1}, \mathrm{C} 3: 0.176 \mu \mathrm{g} \mathrm{mL}^{-1}, \mathrm{C} 4: 0.53 \mu \mathrm{g} \mathrm{m}^{-1}$. For encapsulated T2fQf the tested concentrations were: control: $0 \mu \mathrm{g} \mathrm{mL}^{-1}, \mathrm{C} 1: 0.15 \mu \mathrm{g} \mathrm{mL}^{-1}, \mathrm{C} 2: 0.44 \mu \mathrm{g} \mathrm{mL}^{-1}, \mathrm{C} 3: 1.33 \mu \mathrm{g} \mathrm{mL}{ }^{-1}, \mathrm{C} 4: 4 \mu \mathrm{gL}^{-1}$. From the four columns in every concentration, the first two columns from the left are the proliferation of the CPN (left) and staurosporine (right), and on the other two columns is the apoptosis of the CPN (left) and staurosporine (right).

Notably, treatment with the encapsulated T2fQf results in higher apoptotic cell numbers, as compared to staurosporine (Fig. 4D), a result that could be attributed to the fact that these CPNs were administered in about 10 -fold higher concentrations than the antibiotic; however, this effect that does not occur after incubation of these cells with the same concentrations of the encapsulated T2fQ2f. These results further support that the nanoprecipitated T2fQf and T2fQ2f along with the encapsulated T2fQ2f could potentially be safely used in bioimaging applications, however more in vivo experiments should be performed.

Regarding the comparative effect of the antibiotic and the CPNs on MDA-MB-231 cells, staurosporine is more effective in slowing down the cell proliferation than the nanoprecipitated
T2fQf and T2fQ2f, which, nevertheless, increase apoptotic cell numbers to a higher extent after longer incubation periods (Fig. 4B and 5B). More interesting are the results involving T-47D cells, in which nanoprecipitated T2fQf induces apoptosis with significantly higher efficiency than the antibiotic (Fig. 4C). On the contrary, the effects of staurosporine are more intense than those induced by the nanoprecipitated T2fQ2f (Fig. 5C). Finally, as shown above, the effect of the respective encapsulated nanoparticles on the two cancer cell lines is not comparable to that of staurosporine, since both MDA-MB-231 and T-47D are insensitive to CPN treatment.

In total, among the tested CPNs, the encapsulated nanoparticles are the least cytotoxic to both cancer and non-tumorigenic cell 


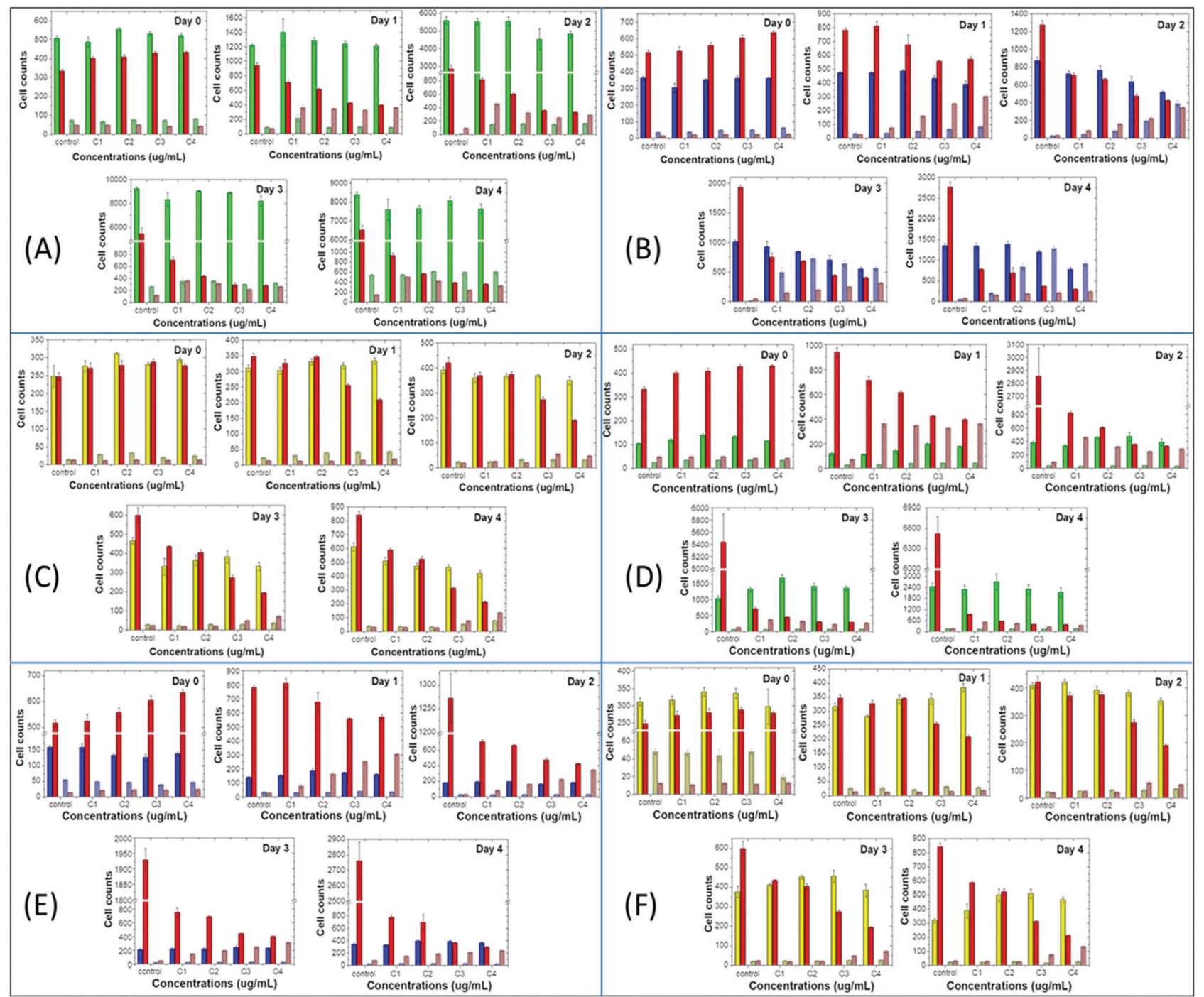

Fig. 5 Comparison of the effect of T2fQ2f with that of the antibiotic staurosporine on the proliferation and apoptosis of breast cancer and non-tumorigenic cell lines. Cell proliferation and late apoptotic cell numbers were estimated for ( $A$ and D). MCF10A, (B and E) MDA-MB-231 and (C and F). T-47D cells, by Hoechst/DAPI and PI staining, respectively, after treatment of the cells with increasing concentrations of staurosporine and T2fQ2f acquired by either the nanoprecipitation (AC), or the encapsulation (D-F) method, every $24 \mathrm{~h}$, over a period of four days. Day 0 is the day of treatment initiation. Data are presented as mean of cell counts compared with the negative control. SD was used for error bar generation. For staurosporine, the following concentrations were used: control: $0.0044 \mu \mathrm{g} \mathrm{mL}{ }^{-1}$, C1: $0.0133 \mu \mathrm{g} \mathrm{mL}^{-1}, \mathrm{C} 2: 0.040 \mu \mathrm{g} \mathrm{mL}^{-1}, \mathrm{C} 3: 0.120 \mu \mathrm{g} \mathrm{mL}^{-1}, \mathrm{C} 4: 0.360 \mu \mathrm{g} \mathrm{mL}^{-1}$. The corresponding concentrations for nanoprecipitated T2fQ2f were: control: $0 \mu \mathrm{g} \mathrm{mL}-1, \mathrm{C} 1: 0.015 \mu \mathrm{g} \mathrm{mL}^{-1}, \mathrm{C} 2: 0.044 \mu \mathrm{g} \mathrm{m}^{-1}, \mathrm{C} 3: 0.133 \mu \mathrm{g} \mathrm{mL}^{-1}, \mathrm{C} 4: 0.4 \mu \mathrm{g} \mathrm{mL}^{-1}$. For encapsulated T2fQf the tested concentrations were: control: $0 \mu \mathrm{gL}^{-1}, \mathrm{C} 1: 0.15 \mu \mathrm{g} \mathrm{mL}^{-1}, \mathrm{C} 2: 0.44 \mu \mathrm{g} \mathrm{mL}^{-1}, \mathrm{C} 3: 1.33 \mu \mathrm{g} \mathrm{mL}^{-1}, \mathrm{C} 4: 4 \mu \mathrm{g} \mathrm{mL}^{-1}$. From the four columns in every concentration, the first two columns from the left are the proliferation of the CPN (left) and staurosporine (right), and on the other two columns is the apoptosis of the CPN (left) and staurosporine (right).

lines, with the exception of T2fQf, which induces undesirably elevated levels of apoptosis in MCF10A. Regarding the nanoprecipitated CPNs, both T2fQf and T2fQ2f are well tolerated by all cell lines in low concentrations and for early time-point treatment. However, higher concentrations of nanoprecipitated T2fQf induce apoptosis to a great extent in cancer cells, and not in normal-like cells, thus pointing out a putative therapeutic potential for this specific type of CPN.

\section{Evaluation of the ability of the CPNs to be introduced and detected intracellularly}

In order to evaluate their potential application for intracellular imaging protocols, selected concentrations of the nanoprecipitated and encapsulated T2fQf and T2fQ2f were further tested for their ability to enter the cell cytoplasm and to give detectable fluorescent signals. For this purpose, each of the nanoprecipitated and encapsulated CPNs were administered to MDA-MB231, T-47D and MCF10A cells for $24 \mathrm{~h}$. Then, cellular fluorescence was analyzed by FACS and confirmed by confocal microscopy (Fig. 6 and 7).

The selected concentrations were the highest possible common choice for all of the CPNs, with minimum effects on cell proliferation and survival of all three cell lines (Fig. 2 and 3). More specifically, the following concentrations were tested: $0.176 \mu \mathrm{g} \mathrm{mL} \mathrm{mL}^{-1}$ of nanoprecipitated T2fQf, $0.133 \mu \mathrm{g} \mathrm{mL} \mathrm{L}^{-1}$ of nanoprecipitated T2fQ2f, $1.33 \mu \mathrm{g} \mathrm{mL} \mathrm{m}^{-1}$ of encapsulated T2fQf, 
or $1.33 \mu \mathrm{g} \mathrm{mL} \mathrm{mL}^{-1}$ of encapsulated T2fQ2f. FACS analysis of the CPN-treated cells revealed that none of the CPNs was detected within MCF10A cells (Fig. 6B). The nanoprecipitated T2fQf was the only one out of the four tested nanoparticles, which was uptaken by both cancer cell lines, although to a different extent (Fig. 6).

In detail, almost $80 \%$ of MDA-MB-231 cells and about $30 \%$ of T-47D cells were labelled. In sharp contrast, less than $0.15 \%$ of MCF10A normal-like breast epithelial cells were positively stained (Fig. 6D). These results suggest that there might be some specificity of the nanoprecipitated T2fQf for aggressive breast cancer cells, albeit more cell lines should be tested to verify the proposed hypothesis. There was no positive fluorescent signal for all other CPNs (nanoprecipitated T2fQ2f and encapsulated CPNs), indicating that none of them are detected into the cells (Fig. 6A-D). Potentially, higher concentrations of those nanoparticles could be noticed within the cells, but they were not further tested due to their cytotoxicity.

The FACS analysis results were further confirmed by fluorescence microscopy. In this experiment, the cell nuclei were stained with Hoechst and were visualized using a confocal microscope. Two different lasers were used to detect CPN fluorescence, namely $568 \mathrm{~nm}$ and $594 \mathrm{~nm}$. Confocal microscopy confirmed that only the nanoprecipitated T2fQf was introduced into the cell cytoplasm; most MDA-MB-231 cells (90\%) were positive for the nanoparticle while only weak fluorescent signals and no fluorescence were acquired for T-47D and MCF10A cells, respectively (Fig. 7). The exclusion of encapsulated T2fQf and T2fQ2f from both cancer cell lines in addition to the exclusion of the nanoprecipitated and encapsulated T2fQ2f from MCF10A could possibly explain the cell insensitivity to CPN treatment. Nevertheless, although not detected in MCF10A, both nanoprecipitated and encapsulated T2fQf induce high apoptotic cell numbers, indicating that those CPNS could possibly trigger alternative cell death responses, without themselves being intracellularly present. One reason for the different cellular uptake of similar concentrations of the nanoprecipitated T2fQf and T2fQ2f could be the additional fluorine atom present in T2fQ2f rendering it suitable for membrane penetration.
(A)

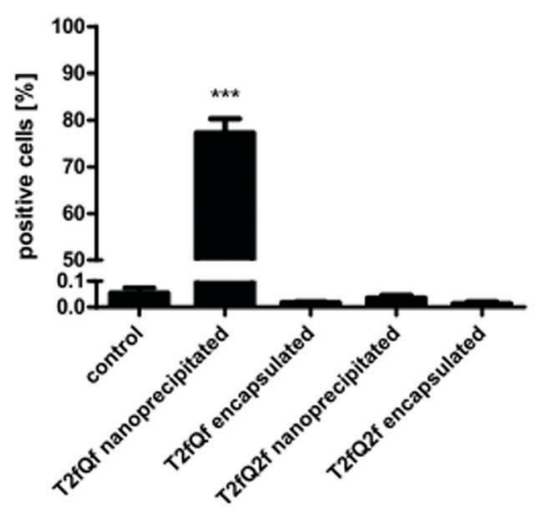

(D)

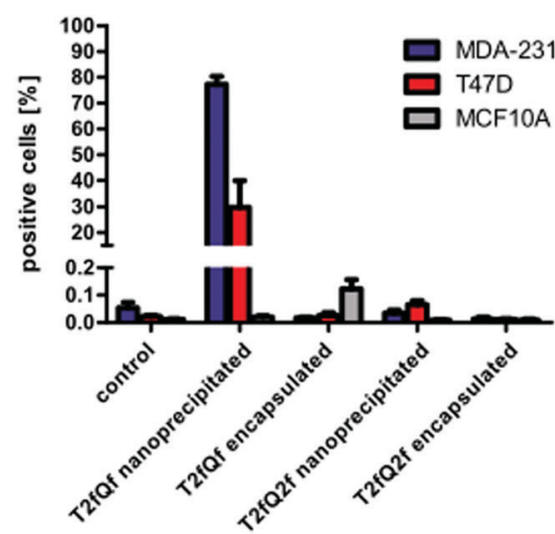

(B)

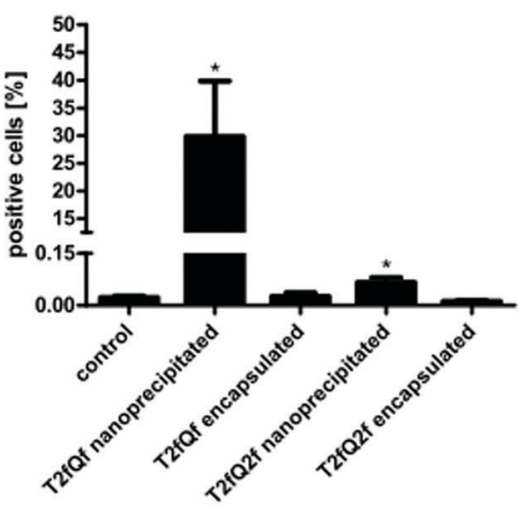

(E)

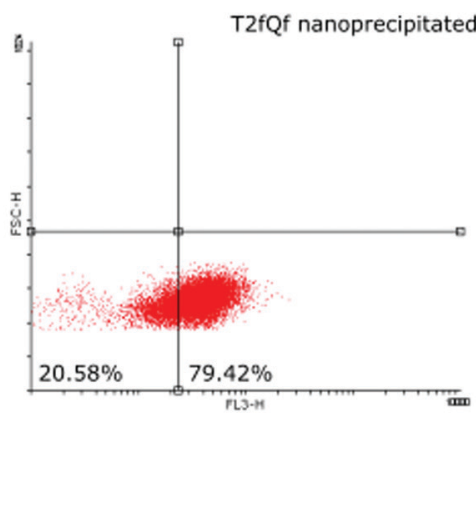

(C)

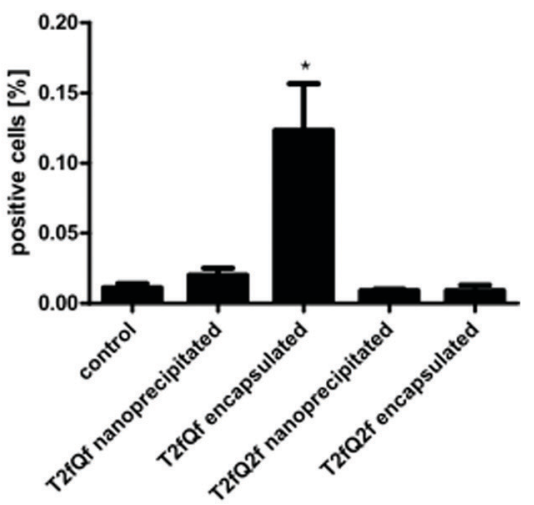

$(\mathrm{F})$

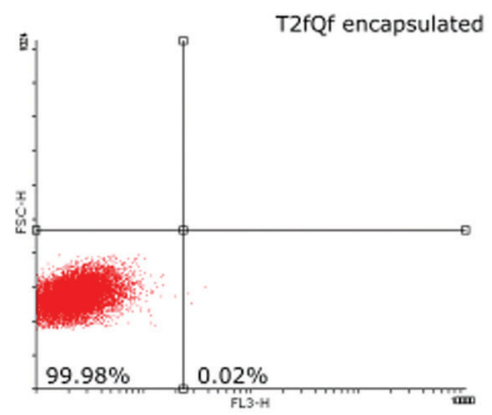

Fig. 6 Estimation of cellular uptake of different CPNs by FACS analysis. (A) MDA-MB-231, (B) T-47D and (C) MCF10A cells were incubated with different nanoparticles or PBS as a control for 24 hours. Percentages of cells containing nanoparticles were determined by FACS and plotted. Data are presented as mean $\pm \mathrm{SD}, n=3$ (each with 3 technical replicates). Statistical analysis was performed by unpaired two-tailed Student's $t$-test; ${ }^{* *} p<0.001,{ }^{\star} p<$ 0.05. (D) Summarized plotted data showing the comparison of the mean percentage of positive cells between the tested cell lines. (E and $F$ ) Representative Dotplots of living MDA-MB-231 cells treated with nanoprecipitated (E) or encapsulated T2fQf (F). The nanoparticles were detected with FL3 filter. Bottom-left area shows percentage of negative cells and bottom-right area shows a percentage of positive cells for the indicated nanoparticle. 
(A) MCF10A

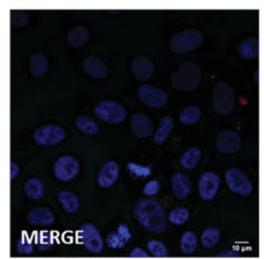

(C) MCF10A

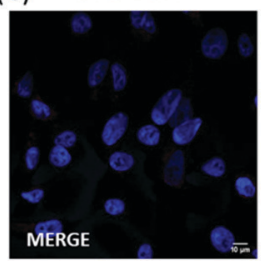

(E) MCF10A

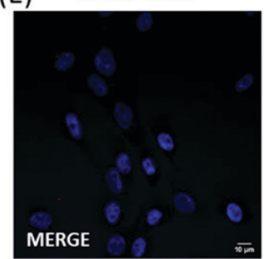

MDA-MB-231

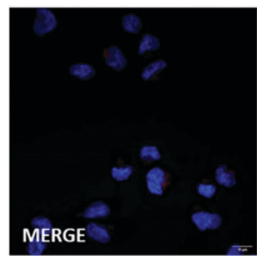

MDA-MB-231

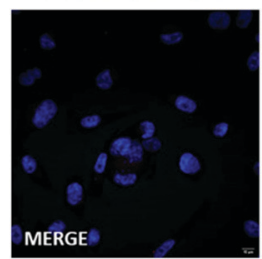

MDA-MB-231

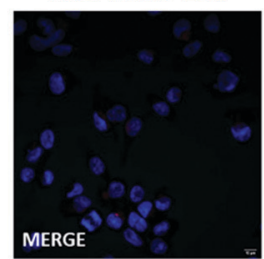

T-47D

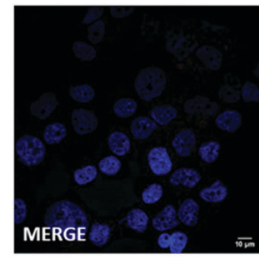

T-47D

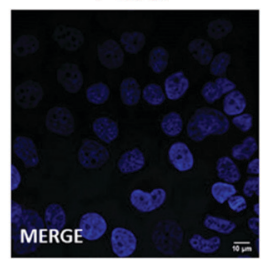

T-47D

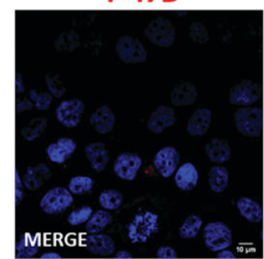

(B) MCF10A

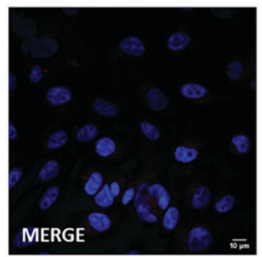

(D) MCF10A

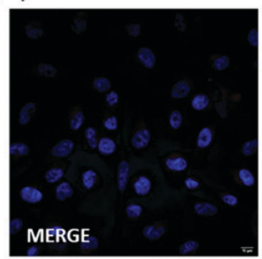

MDA-MB-231

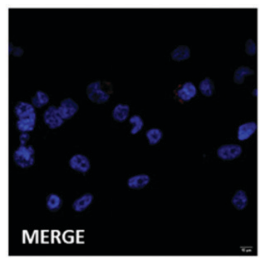

MDA-MB-231

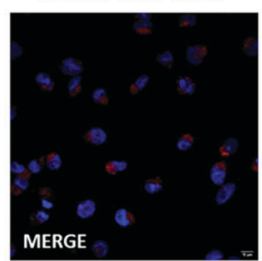

T-47D

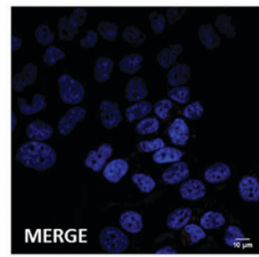

T-47D

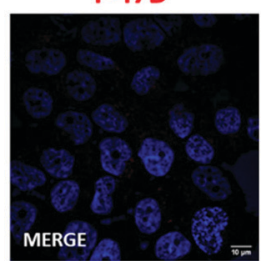

Fig. 7 Estimation of cellular uptake of different CPNs by confocal fluorescence microscopy. Merged confocal fluorescence images of cell nuclei

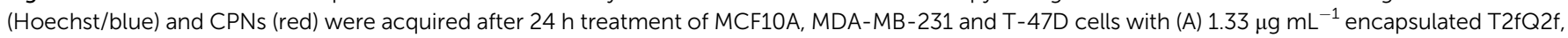
(B) $0.133 \mu \mathrm{g} \mathrm{mL}^{-1}$ nanoprecipitated T2fQ2f, (C) $1.33 \mu \mathrm{g} \mathrm{mL} \mathrm{L}^{-1}$ encapsulated T2fQf, or (D) $0.176 \mu \mathrm{g} \mathrm{mL}{ }^{-1}$ nanoprecipitated T2fQf. (E) Negative control. Magnification $63 x$

Taking the above into consideration, the presented results show that the T2fQf nanoparticles formulated by the nanoprecipitation method can enter into MDA-MB-231 cells with high efficacy and into T-47D cells to a lesser extent whereas no uptake is shown for the MCF10A. This observation could be explained by differences in both the gene profile and the morphology of these distinct cell lines. ${ }^{54-57}$ For example, MCF10A and T-47D cells express low levels of the proliferative marker Ki-67 and high E-cadherin levels and claudins, the most important protein components of tight junctions; hence, these cells have an epithelial morphology and display robust cell-cell cohesions, required for paracellular communication. On the contrary, triple negative MDA-MB-231 cells show a more mesenchymal-like phenotype, with low levels of claudins and E-cadherin and expression of markers of epithelial-mesenchymal transition such as vimentin. ${ }^{54-57}$ Moreover, low concentrations of the nanoprecipitated T2fQf are well tolerated by both cancer and non-tumorigenic cell lines and for shorter treatment periods; based on the above, at the in vitro level, nanoprecipitated T2fQf fulfils the requirements for use in bioimaging applications.

Interestingly, higher concentrations trigger apoptosis in cancer cells, and not in normal-like cells, making the T2fQf CPNs an attractive candidate for exploitation for therapeutic interventions. The efficacy of nanoprecipitated T2fQf against a triple negative, metastatic breast cancer cell line, is of particular interest, since, due to the nature of these tumors, the main therapeutic options for these patients are restricted to aggressive regimes, like chemotherapy, surgery and radiation; ${ }^{49}$ however, more in vitro and in vivo experiments are needed in order to fully characterize the putative anti-tumorigenic effects of the nanoprecipitated T2fQf CPNs. To this direction, the intrinsic anti-proliferative and apoptosis-inducing properties of nanoprecipitated T2fQf could possibly enhance the action of anti-cancer compounds, which have shown partial efficacy against MDA-MB-231 cells. $^{58,59}$ Encapsulation of such compounds within the nanoparticle could lead to synergistic anti-tumorigenic effects.

\section{Conclusions}

In this study we presented one of the limited studies on the rational design of CPNs for specific biological purposes. In particular, it is demonstrated the in vitro cell viability and cytotoxicity tests of T2fQf and T2fQ2f CPNs prepared via the nanoprecipitation and the encapsulation method on two different malignant human breast cell lines compared with a non-malignant epithelial cell line. The obtained results showed that both the nanoprecipitated and the encapsulated T2fQ2f CPNs, as well as the T2fQf prepared via the nanoprecipitation method could potentially be used for imaging applications. However, FACS analysis and confocal microscopy confirmed that only the nanoprecipitated T2fQf CPNs were introduced into the cell cytoplasm of both breast cancer cell lines, especially into MDA-MB-231 cells with high efficacy. The evaluation of the comparison of the effect of the CPNs on cell proliferation and apoptosis of all cell lines with the corresponding of the antibiotic staurosporine revealed that the higher 
concentrations of T2fQf nanoprecipitated CPNs induce apoptosis to a great extent in cancer cell lines, and not in normal-like cells, indicating a putative therapeutic potential for these specific CPNs. Furthermore, the efficacy of the nanoprecipitated T2fQf CPNs against the MDA-MB-231 triple negative, highly aggressive and metastatic breast cancer cell line is of particular interest, since limited therapeutic options are currently available due to the nature of those tumors. Overall, the intrinsic anti-proliferative and apoptosis-inducing properties of nanoprecipitated T2fQf CPNs could possibly enhance the action of anti-cancer compounds, which have shown partial efficacy against MDA-MB-231 cells and the encapsulation of such compounds within the nanoparticle could lead to synergistic anti-tumorigenic effects.

\section{Conflicts of interest}

There are no conflicts to declare.

\section{Acknowledgements}

This research has received funding by the Helmholtz European partnering program for the cooperation between German Cancer Research Center (DKFZ) and National Hellenic Research Foundation (NHRF) to build the Athens Comprehensive Cancer Center (ACCC). P. K. acknowledges the Operational Programme "Human Resources Development, Education and Lifelong Learning" in the context of the project "Reinforcement of Postdoctoral Researchers - 2nd Cycle" (MIS-5033021), implemented by the State Scholarships Foundation (IKY) cofinanced by Greece and the European Union (European Social Fund-ESF). M. G. would like to thank Pfizer Hellas S. A. for the financial support through the Pfizer fellowship.

\section{References}

1 F. Bray, J. Ferlay, I. Soerjomataram, R. L. Siegel, L. A. Torre and A. Jemal, Global cancer statistics 2018: GLOBOCAN estimates of incidence and mortality worldwide for 36 cancers in 185 countries, Ca-Cancer J. Clin., 2018, 68, 394.

2 R. Jenkins, M. K. Burdette and S. H. Foulger, Mini-review: Fluorescence imaging in cancer cells using dye-doped nanoparticles, RSC Adv., 2016, 6, 65459.

3 H. Ma, D. Hu, J. Zhao, M. Tian, J. Yuan and Y. Wei, Ultrastable Near-Infrared Aggregation-Induced Emission Nanoparticles as a Fluorescent Probe: Long-Term Tumor Monitoring and Lipid Droplet Tracking, CCS Chem., 2020, 2, 1569.

4 J. Shi, P. W. Kantoff, R. Wooster and O. C. Farokhzad, Cancer nanomedicine: progress, challenges and opportunities, Nat. Rev. Cancer, 2017, 17, 20.

5 Y. Cheng, C. Sun, X. Ou, B. Liu, X. Lou and F. Xia, Dualtargeted peptide-conjugated multifunctional fluorescent probe with AIEgen for efficient nucleus-specific imaging and long-term tracing of cancer cells, Chem. Sci., 2017, 8, 4571.

6 Y. Guan, T. Sun, J. Ding and Z. Xie, Robust organic nanoparticles for noninvasive long-term fluorescence imaging, J. Mater. Chem. B, 2019, 7, 6879.

7 V. Paefgen, D. Doleschel and F. Kiessling, Evolution of contrast agents for ultrasound imaging and ultrasoundmediated drug delivery, Front. Pharmacol., 2015, 6, 1.

8 K. Park, S. Lee, E. Kang, K. Kim, K. Choi and I. C. Kwon, New Generation of Multifunctional Nanoparticles for Cancer Imaging and Therapy, Adv. Funct. Mater., 2009, 19, 1553.

9 L. Cheng, J. Liu, X. Gu, H. Gong, X. Shi, T. Liu, C. Wang, X. Wang, G. Liu, H. Xing, W. Bu, B. Sun and Z. Liu, PEGylated $\mathrm{WS}_{2}$ Nanosheets as a Multifunctional Theranostic Agent for in vivo Dual-Modal CT/Photoacoustic Imaging Guided Photothermal Therapy, Adv. Mater., 2014, 26, 1886.

10 S. K. Mishra and S. Kannan, Doxorubicin-Conjugated Bimetallic Silver-Gadolinium Nanoalloy for Multimodal MRICT-Optical Imaging and pH-Responsive Drug Release, ACS Biomater. Sci. Eng., 2017, 3, 3607.

11 H. Bin, Na, I. C. Song and T. Hyeon, Inorganic Nanoparticles for MRI Contrast Agents, Adv. Mater., 2009, 21, 2133.

12 J. Li, T. Wang, Y. Feng, Y. Zhang, M. Zhen, C. Shu, L. Jiang, Y. Wang and C. Wang, A water-soluble gadolinium metallofullerenol: facile preparation, magnetic properties and magnetic resonance imaging application, Dalton Trans., 2016, 45, 8696.

13 X. Ning, W. Seo, S. Lee, K. Takemiya, M. Rafi, X. Feng, D. Weiss, X. Wang, L. Williams, V. M. Camp, M. Eugene, W. R. Taylor, M. Goodman and N. Murthy, PET Imaging of Bacterial Infections with Fluorine-18-Labeled Maltohexaose, Angew. Chem., Int. Ed., 2014, 53, 14096.

14 C. Sachpekidis, H. Goldschmidt and A. DimitrakopoulouStrauss, Positron emission tomography (PET) radiopharmaceuticals in multiple myeloma, Molecules, 2020, 25, 134.

15 A. Dimitrakopoulou-Strauss, PET-based molecular imaging in personalized oncology: Potential of the assessment of therapeutic outcome, Future Oncol., 2015, 11, 1083.

16 S. M. Janib, A. S. Moses and J. A. MacKay, Imaging and drug delivery using theranostic nanoparticles, Adv. Drug Delivery Rev., 2010, 62, 1052.

17 S. Kim, C. K. Lim, J. Na, Y. D. Lee, K. Kim, K. Choi, J. F. Leary and I. C. Kwon, Conjugated polymer nanoparticles for biomedical in vivo imaging, Chem. Commun., 2010, 46, 1617.

18 C. G. Qian, Y. L. Chen, P. J. Feng, X. Z. Xiao, M. Dong, J. C. Yu, Q. Y. Hu, Q. D. Shen and Z. Gu, Conjugated polymer nanomaterials for theranostics, Acta Pharmacol. Sin., 2017, 38, 764 .

19 M. A. Pysz, S. S. Gambhir and J. K. Willmann, Molecular imaging: current status and emerging strategies, Clin. Radiol., 2010, 65, 500.

20 A. Miyawaki and Y. Niino, Molecular Spies for BioimagingFluorescent Protein-Based Probes, Mol. Cell, 2015, 58, 632.

21 Y. Nasu, Y. Asaoka, M. Namae, H. Nishina, H. Yoshimura and T. Ozawa, Genetically Encoded Fluorescent Probe for Imaging Apoptosis in vivo with Spontaneous GFP Complementation, Anal. Chem., 2016, 88, 838. 
22 T. Wedeking, S. Löchte, C. P. Richter, M. Bhagawati, J. Piehler and C. You, Single Cell GFP-trap reveals stoichiometry and dynamics of cytosolic protein complexes, Nano Lett., 2015, 15, 3610.

23 J. Li, W. Y. W. Lee, T. Wu, J. Xu, K. Zhang, D. S. Hong Wong, R. Li, G. Li and L. Bian, Near-infrared light-triggered release of small molecules for controlled differentiation and longterm tracking of stem cells in vivo using upconversion nanoparticles, Biomaterials, 2016, 110, 1.

24 D. Franke, D. K. Harris, O. Chen, O. T. Bruns, J. A. Carr, M. W. B. Wilson and M. G. Bawendi, Continuous injection synthesis of indium arsenide quantum dots emissive in the short-wavelength infrared, Nat. Commun., 2016, 7, 1.

25 Y. Wu, Q. Wang, T. Wu, W. Liu, H. Nan, S. Xu and Y. Shen, Detection and Imaging of Hydrogen Sulfide in Lysosomes of Living Cells with Activatable Fluorescent Quantum Dots, ACS Appl. Mater. Interfaces, 2018, 10, 43472.

26 G. Hong, S. Diao, J. Chang, A. L. Antaris, C. Chen, B. Zhang, S. Zhao, D. N. Atochin, P. L. Huang, K. I. Andreasson, C. J. Kuo and H. Dai, Through-skull fluorescence imaging of the brain in a new near-infrared window, Nat. Photonics, 2014, 8, 723.

27 K. Welsher, Z. Liu, S. P. Sherlock, J. T. Robinson, Z. Chen, D. Daranciang and H. Dai, A route to brightly fluorescent carbon nanotubes for near-infrared imaging in mice, Nat. Nanotechnol., 2009, 4, 773.

28 L. Liu, S. Wang, B. Zhao, P. Pei, Y. Fan, X. Li and F. Zhang, $\mathrm{Er}^{3+}$ Sensitized $1530 \mathrm{~nm}$ to $1180 \mathrm{~nm}$ Second Near-Infrared Window Upconversion Nanocrystals for in Vivo Biosensing, Angew. Chem., Int. Ed., 2018, 57, 7518.

29 W. Shao, G. Chen, A. Kuzmin, H. L. Kutscher, A. Pliss, T. Y. Ohulchanskyy and P. N. Prasad, Tunable Narrow Band Emissions from Dye-Sensitized Core/Shell/Shell Nanocrystals in the Second Near-Infrared Biological Window, J. Am. Chem. Soc., 2016, 138, 16192.

30 T. F. Abelha, C. A. Dreiss, M. A. Green, L. A. Dailey and T. F. Abelha, Conjugated polymers as nanoparticle probes for fluorescence and photoacoustic imaging, J. Mater. Chem. $B, 2020,8,592$.

31 J. Mei, N. L. C. Leung, R. T. K. Kwok, J. W. Y. Lam and B. Z. Tang, Aggregation-Induced Emission: Together We Shine, United We Soar!, Chem. Rev., 2015, 115, 11718.

32 A. M. Derfus, W. C. W. Chan and S. N. Bhatia, Probing the Cytotoxicity of Semiconductor Quantum Dots, Nano Lett., 2004, 4, 11.

33 G. Feng, J. Liu, J. Geng and B. Liu, Conjugated polymer microparticles for selective cancer cell image-guided photothermal therapy, J. Mater. Chem. B, 2015, 3, 1135.

34 K. Li and B. Liu, Polymer encapsulated conjugated polymer nanoparticles for fluorescence bioimaging, J. Mater. Chem., 2012, 22, 1257.

35 D. Gao, D. Hu, X. Liu, X. Zhang, Z. Yuan, Z. Sheng and H. Zheng, Recent Advances in Conjugated Polymer Nanoparticles for NIR-II Imaging and Therapy, ACS Appl. Polym. Mater., 2020, 2, 4241.

36 M. Sun, B. Sun, Y. Liu, Q. D. Shen and S. Jiang, Dual-Color Fluorescence Imaging of Magnetic Nanoparticles in Live
Cancer Cells Using Conjugated Polymer Probes, Sci. Rep., 2016, 6, 1.

37 J. Choi, H. Kim and Y. Choi, Theranostic nanoparticles for enzyme-activatable fluorescence imaging and photodynamic/chemo dual therapy of triple-negative breast cancer, Quant. Imaging Med. Surg., 2015, 5, 656.

38 W. Wu, G. Feng, S. Xu and B. Liu, A Photostable Far-Red/ Near-Infrared Conjugated Polymer Photosensitizer with Aggregation-Induced Emission for Image- Guided Cancer Cell Ablation, Macromolecules, 2016, 49, 5017.

39 L. Feng, J. Zhu and Z. Wang, Biological Functionalization of Conjugated Polymer Nanoparticles for Targeted Imaging and Photodynamic Killing of Tumor Cells, ACS Appl. Mater. Interfaces, 2016, 8, 19364.

40 P. Koralli, A. D. Nega, L. E. Vagiaki, A. Pavlou, M. G. Siskos, A. Dimitrakopoulou-Strauss, V. G. Gregoriou and C. L. Chochos, New conjugated polymer nanoparticles with high photoluminescence quantum yields for far-red and near infrared fluorescence bioimaging, Mater. Chem. Front., 2020, 4, 2357.

41 R. L. Siegel, K. D. Miller, H. E. Fuchs and A. Jemal, Cancer Statistics, 2021, Ca-Cancer J. Clin., 2021, 71, 7.

42 Y. Wang, L. Jiang, Y. Zhang, Y. Lu, J. Li, H. Wang, D. Yao and D. Wang, Fibronectin-Targeting and Cathepsin-BActivatable Theranostic Nanoprobe for MR/Fluorescence Imaging and Enhanced Photodynamic Therapy for Triple Negative Breast Cancer, ACS Appl. Mater. Interfaces, 2020, $12,33564$.

43 B. L. Eckhardt, P. A. Francis, B. S. Parker and R. L. Anderson, Strategies for the discovery and development of therapies for metastatic breast cancer, Nat. Rev. Drug Discovery, 2012, 11, 479.

44 A. Juan, F. J. Cimas, I. Bravo, A. Pandiella, A. Ocaña and C. Alonso-Moreno, An Overview of Antibody Conjugated Polymeric Nanoparticles for Breast Cancer Therapy, Pharmaceutics, 2020, 12, 1.

45 Z. B. X. Dai, L. Xiang and T. Li, Cancer hallmarks, biomarkers and breast cancer molecular subtypes, J. Cancer, 2016, 7, 1281.

46 J. He, T. Peng, Y. Peng, L. Ai, Z. Deng, X. Q. Wang and W. Tan, Molecularly Engineering Triptolide with Aptamers for High Specificity and Cytotoxicity for Triple-Negative Breast Cancer, J. Am. Chem. Soc., 2020, 142, 2699.

47 S. P. Shah, A. Roth, R. Goya, A. Oloumi, G. Ha, Y. Zhao, G. Turashvili, J. Ding, K. Tse, G. Haffari, A. Bashashati, L. M. Prentice, J. Khattra, A. Burleigh, D. Yap, V. Bernard, A. McPherson, K. Shumansky, A. Crisan, R. Giuliany, A. Heravi-Moussavi, J. Rosner, D. Lai, I. Birol, R. Varhol, A. Tam, N. Dhalla, T. Zeng, K. Ma, S. K. Chan, M. Griffith, A. Moradian, S. W. G. Cheng, G. B. Morin, P. Watson, K. Gelmon, S. Chia, S. F. Chin, C. Curtis, O. M. Rueda, P. D. Pharoah, S. Damaraju, J. MacKey, K. Hoon, T. Harkins, V. Tadigotla, M. Sigaroudinia, P. Gascard, T. Tlsty, J. F. Costello, I. M. Meyer, C. J. Eaves, W. W. Wasserman, S. Jones, D. Huntsman, M. Hirst, C. Caldas, M. A. Marra and S. Aparicio, The clonal and mutational evolution spectrum 
of primary triple negative breast cancers, Nature, 2012, 486, 395.

48 R. Dent, M. Trudeau, K. I. Pritchard, W. M. Hanna, H. K. Kahn, C. A. Sawka, L. A. Lickley, E. Rawlinson, P. Sun and S. A. Narod, Triple-Negative Breast Cancer: Clinical Features and Patterns of Recurrence, Clin. Cancer Res., 2007, 13, 4429.

49 G. Jin, R. He, Q. Liu, Y. Dong, M. Lin, W. Li and F. Xu, Theranostics of Triple-Negative Breast Cancer Based on Conjugated Polymer Nanoparticles, ACS Appl. Mater. Interfaces, 2018, 10, 10634.

50 G. Jin, G. Feng, W. Qin, B. Z. Tang, B. Liu and K. Li, Multifunctional organic nanoparticles with aggregationinduced emission (AIE) characteristics for targeted photodynamic therapy and RNA interference therapy, Chem. Commun., 2016, 52, 2752.

51 M. Doshi, M. Krienke, S. Khederzadeh, H. Sanchez, A. Copik, J. Oyer and A. J. Gesquiere, Conducting Polymer Nanoparticles for Targeted Cancer Therapy, RSC Adv., 2015, 5, 37943.

52 Z. Zhang, K. Teruya, H. Eto and S. Shirahata, Induction of Apoptosis by Low-Molecular-Weight Fucoidan through Calcium- and Caspase-Dependent Mitochondrial Pathways in MDA-MB-231 Breast Cancer Cells, Biosci., Biotechnol., Biochem., 2013, 77, 235.

53 L. Cyr, R. Langler and C. Lavigne, Cell Cycle Arrest and Apoptosis Responses of Human Breast Epithelial Cells to the Synthetic Organosulfur Compound p-Methoxyphenyl p-Toluenesulfonate, Anticancer Res., 2008, 28, 2753.

54 K. K. Brodaczewska, C. Szczylik, M. Fiedorowicz, C. Porta and A. M. Czarnecka, Choosing the right cell line for renal cell cancer research, Mol. Cancer, 2016, 15, 1.

55 P. G. Webb, M. A. Spillman and H. K. Baumgartner, Claudins play a role in normal and tumor cell motility, BMC Cell Biol., 2013, 14, 1.

56 A. A. Blanchard, X. Ma, N. Wang, S. Hombach, C. Penner, A. Ozturk, T. Klonisch, M. Pitz, L. Murphy, E. Leygue and Y. Myal, Claudin 1 Is Highly Upregulated by PKC in MCF7 Human Breast Cancer Cells and Correlates Positively with PKCE in Patient Biopsies, Transl. Oncol., 2019, 12, 561.

57 K. Subik, J. F. Lee, L. Baxter, T. Strzepek, D. Costello, P. Crowley, L. Xing, M. C. Hung, T. Bonfiglio, D. G. Hicks and P. Tang, The expression patterns of ER, PR, HER2, CK5/ 6, EGFR, Ki-67 and AR by Immunohistochemical Analysis in Breast cancer cell Lines, Breast Cancer: Basic Clin. Res., 2010, 4, 35 .

58 G. D. Basu, L. B. Pathangey, T. L. Tinder, S. J. Gendler and P. Mukherjee, Mechanisms underlying the growth inhibitory effects of the cyclo-oxygenase-2 inhibitor celecoxib in human breast cancer cells, Breast Cancer Res., 2005, 7, R422.

59 F. Mohammed, F. Rashid-Doubell, S. Taha, S. Cassidy and S. Fredericks, Effects of curcumin complexes on MDA-MB231 breast cancer cell proliferation, Int. J. Oncol., 2020, 57,445 . 